\title{
Soybean Cyst Nematode (Heterodera glycines) Distribution in North Carolina, U.S.A.
}

Weimin Ye, ${ }^{\dagger}$ Nematode Assay Section, Agronomic Division, North Carolina Department of Agriculture \& Consumer Services, Raleigh, NC 27607-6465

Accepted for publication 26 October 2017.

Soybean cyst nematode (SCN), Heterodera glycines Ichinohe, is an obligate, sedentary, and devastating parasite that is the number one pathogen of soybean, causing more than twice as much yield loss than any other disease. Estimated annual yield losses in the United States and Canada from 2010 to 2014 were 123,481,000 bushels, worth approximately $\$ 1.2$ billion at $\$ 9.70$ per bushel (Allen et al. 2017). SCN was first discovered in the United States in New Hanover County, North Carolina, in 1954 (Winstead et al. 1955) and is believed to have been introduced from Asia (Riggs 2004). SCN is known to spread rapidly. By 2017, it was found in every soybean-producing state in the United States except for West Virginia (Tylka and Marett 2017).

The North Carolina Department of Agriculture and Consumer Services' (NCDA\&CS) Agronomic Division has analyzed numerous nematode soil samples to monitor the spread and distribution of SCN. Plant-parasitic nematodes in $500 \mathrm{~cm}^{3}$ of soil were extracted by a combination of elutriation (Byrd et al. 1976) and sugar centrifugal flotation (Jenkins 1964) methods. The species identification is based on morphology of cysts and the second-stage juveniles and DNA sequencing on the near-full-length small subunit rDNA gene, internal transcribed spacer, and D2/D3 expansion segments of the large subunit rDNA gene when necessary. This report summarizes lab assay and survey results from July 1, 2014, to June 30, 2017. In this period, 100,118 soil samples were submitted voluntarily for routine nematode assay by growers of various crops in 97 North Carolina counties (Fig. 1). Only Alleghany, Clay, and McDowell counties were not represented in this sample population. SCN was detected in 21,922 of the soil samples $(21.9 \%)$. The overall mean population density on the second-stage juveniles and females was $110 \pm 266$ (10 to 14,600$)$ per $500 \mathrm{~cm}^{3}$ of soil. In 2016, a survey program was launched to collect soil samples from soybean fields located in counties where SCN had not been previously detected by

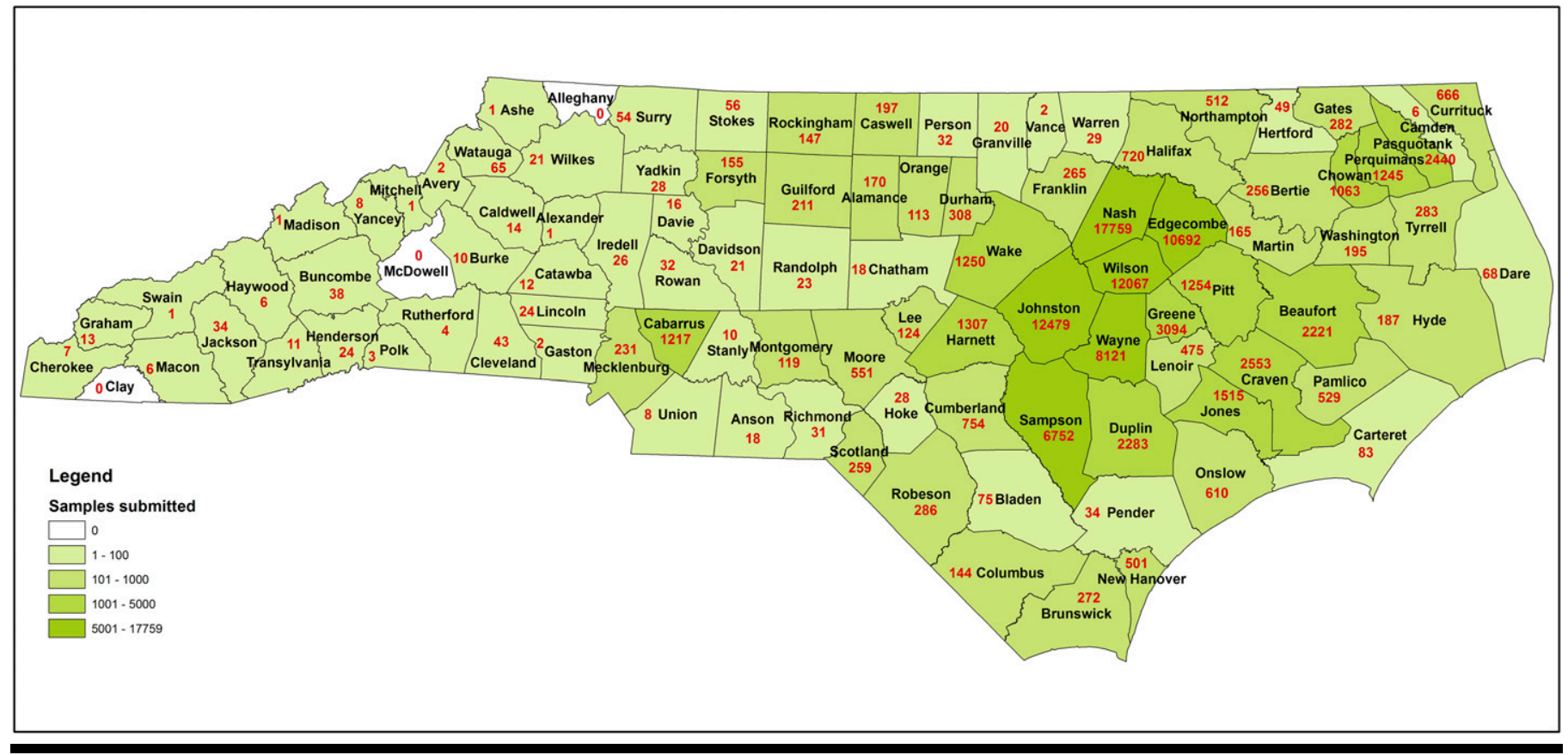

FIGURE 1

Nematode sample source and sample number from each county in North Carolina from July 1, 2014, to June 30, 2017.

${ }^{\dagger}$ Corresponding author: W. Ye; E-mail: Weimin.Ye@ncagr.gov

(C) 2017 The American Phytopathological Society 
NCDA\&CS; regional agronomists collected 244 soil samples from 28 counties in the western part of the state and one coastal county (Dare). Based on the assay results from grower and survey soil samples, Anson, Catawba, Chatham, Dare, and Lincoln counties were added to North Carolina's list of SCN-positive counties documented by June 30, 2014, bringing the total to 57 (Fig. 2). Catawba is the only county not shown on the recent North American SCN distribution map published by Tylka and Marett (2017). It is worthy to note that Dare
County was the only county in the eastern half of the state without SCN in the past, but SCN was found in this survey. SCN was confirmed to be present in 50 counties in North Carolina. None was found in seven counties (Cleveland, Granville, Hoke, Richmond, Union, Vance, and Yadkin) where SCN had been previously identified. Johnston $(3,462$ SCN-positive samples), Wayne (3,274), Nash $(2,960)$, Wilson $(2,039)$, and Pasquotank $(1,513)$ counties had the most SCN-positive samples. Population density (the second-stage juveniles and females of

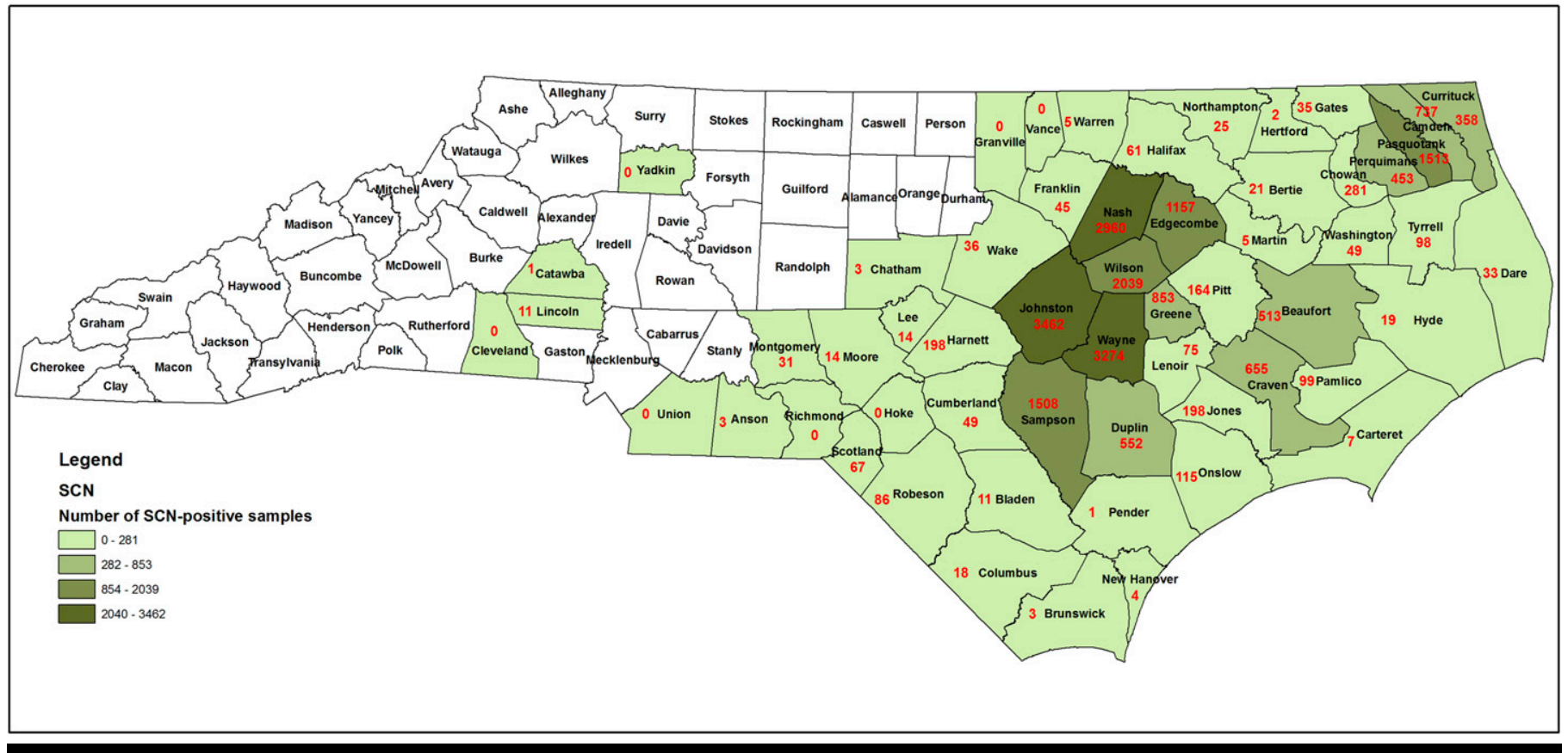

FIGURE 2

Known distribution of soybean cyst nematode (SCN) in North Carolina in 2017 (green counties) and number of positive samples from each county.

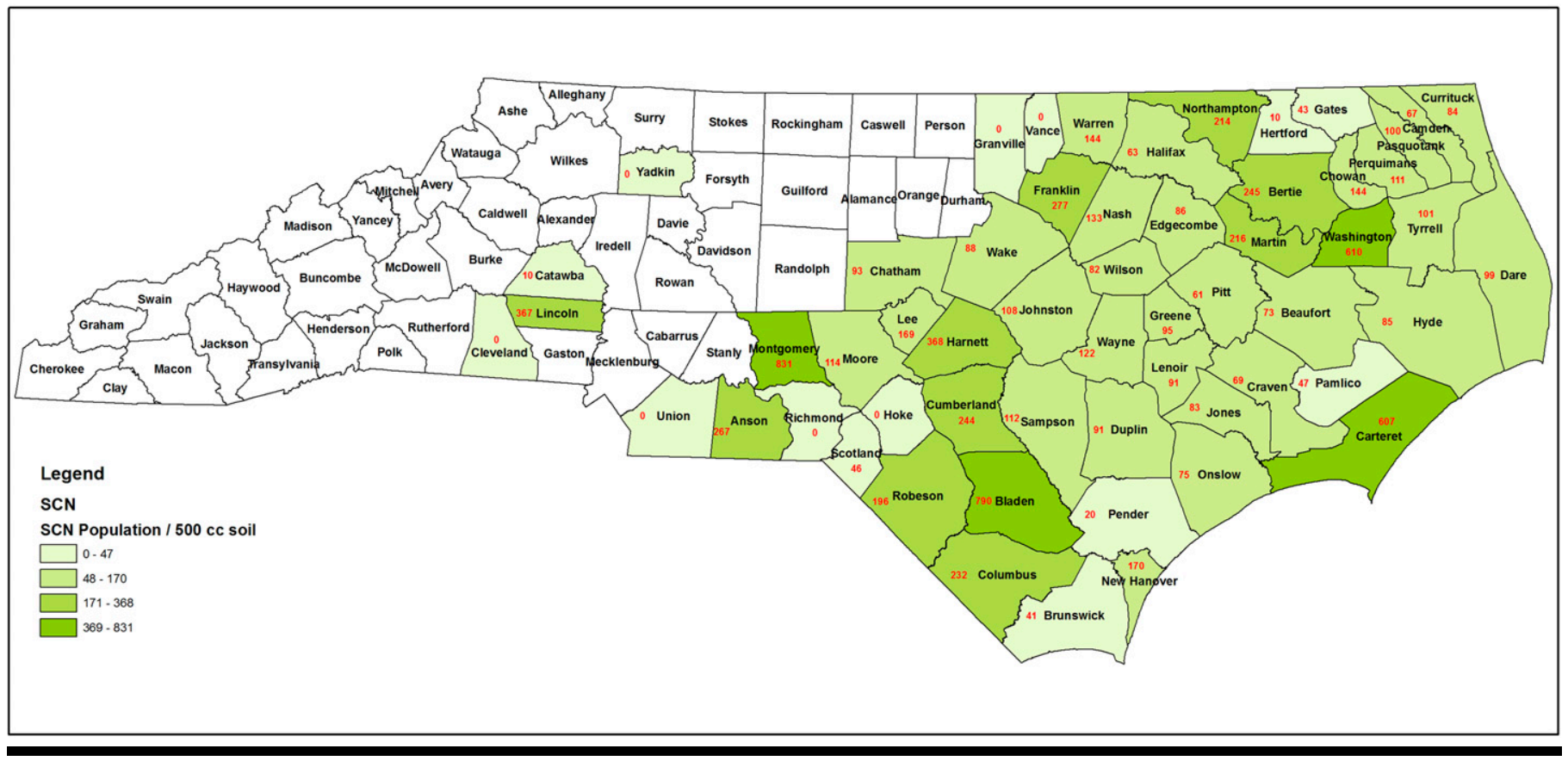

FIGURE 3

Known distribution of soybean cyst nematode (SCN) in North Carolina in 2017 (green counties) and average SCN population density (number of the secondstage juveniles and females of $\mathrm{SCN} / 500 \mathrm{~cm}^{3}$ of soil) from each county. 
$\mathrm{SCN} / 500 \mathrm{~cm}^{3}$ of soil in average) were highest in Montgomery (831), Bladen (790), Washington (610), Carteret (607), and Harnett (368) (Fig. 3). According to the most recent NCDA\&CS data of soybean planted acres and yield statistics by county in North Carolina (http:// www.ncagr.gov/stats/2016AgStat/AgStat2016.pdf), soybean is mainly grown in the eastern half of the state. In general, the SCNnegative counties are those with no soybean acreage or less than 500 planted acres of soybeans in the western part of the state. The high number of samples in this work gave a clear picture of where SCN is occurring in North Carolina and its population density in each county since its first detection in the United States in 1954. Given the yield losses that SCN is capable of causing, we believe SCN continues to be a yield-limiting factor in the state, and growers should be actively managing this obligate parasite to mitigate yield loss.

\section{Literature Cited}

Allen, T. W., Bradley, C. A., Sisson, A. J., Byamukama, E., Chilvers, M. I., Coker, C. M., Collins, A. A., Damicone, J. P., Dorrance, A. E., Dufault, N. S.,
Esker, P. D., Faske, T. R., Giesler, L. J., Grybauskas, A. P., Hershman, D. E., Hollier, C. A., Isakeit, T., Jardine, D. J., Kelly, H. M., Kemerait, R. C., Kleczewski, N. M., Koenning, S. R., Kurle, J. E., Malvick, D. K., Markell, S. G., Mehl, H. L., Mueller, D. S., Mueller, J. D., Mulrooney, R. P., Nelson, B. D., Newman, M. A., Osborne, L., Overstreet, C., Padgett, G. B., Phipps, P. M., Price, P. P., Sikora, E. J., Smith, D. L., Spurlock, T. N., Tande, C. A., Tenuta, A. U., Wise, K. A., and Wrather, J. A. 2017. Soybean yield loss estimates due to diseases in the United States and Ontario, Canada, from 2010 to 2014. Plant Health Prog. 18:19-27.

Byrd, D. W., Jr., Barker, K. R., Ferris, H., Nusbaum, C. J., Griffin, W. E., Small, R. H., and Stone, C. A. 1976. Two semi-automatic elutriators for extracting nematodes and certain fungi from soil. J. Nematol. 8: 206-212.

Jenkins, W. R. 1964. A rapid centrifugal-floatation technique for separating nematodes from soil. Plant Dis. Rep. 48:692.

Riggs, R. D. 2004. History and distribution. Pages 9-39 in: Biology and Management of Soybean Cyst Nematode, 2nd Ed. Walsworth Publishing Company, Marceline, MO.

Tylka, G. L., and Marett, C. C. 2017. Known distribution of the soybean cyst nematode, Heterodera glycines, in the United States and Canada, 1954 to 2017. Plant Health Prog. 18:167-168.

Winstead, N. N., Skotland, C. B., and Sasser, J. N. 1955. Soybean cyst nematode in North Carolina. Plant Dis. Rep. 39:9-11. 